\title{
Journal of Forests
}

2021 Vol. 8, No. 2, pp. 161-170

$\operatorname{ISSN}(e):$ 2409-3807

$\operatorname{ISSN}(p): 2413-8398$

DOI: 10.18488/journal.101.2021.82.161.170

(C) 2021 Conscientia Beam. All Rights Reserved.

check for
updates

\section{ANALYSIS OF ARABLE FARMERS' AGROFORESTRY PRACTICES IN BOKKOS LOCAL GOVERNMENT AREA, PLATEAU STATE, NIGERIA}

(iD) Onuwa, G.C ${ }^{1+}$
Adepoju, A.O
Mailumo, S.S

\author{
${ }^{1,3}$ Department of Agricultural Extension and Management, Federal College \\ of Forestry, Jos, Plateau State, Nigeria. \\ 'Email: onuwag@gmail.com Tel: +2348035606473 \\ ${ }^{s}$ Email: drmailumo247@gmail.com Tel:+2348036338739 \\ ${ }^{2}$ Forestry Research Institute of Nigeria, Ibadan, Oyo State, Nigeria. \\ ־Email:soadepoju2005@gmail.com Tel: +2348035868634.
}

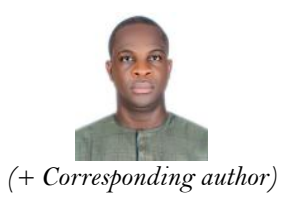

ABSTRACT
Article History

Received: 1 July 2021 Revised: 29 July 2021 Accepted: 17 August 2021 Published: 14 September 2021

\section{Keywords}

Adoption

Agroforestr

Arable farmer

Constraints

Determinants

Index.

\begin{abstract}
The need to increase arable crop production to keep pace with food demands for a growing population without degrading ecosystems can only be achieved through adoption of agroforestry. Agroforestry practices help to achieve food security, biodiversity, conservation and land sustainability. The 94 famers were chosen using a multistage sampling process. Descriptive and inferential statistics were used to analyze the data. Most (74\%) of respondents practiced home gardening. The significant benefits derived from agroforestry were; food/fruits (97\%) and soil improvement/conservation $(88 \%)$. The mean adoption index was 0.27 . The log-likelihood obtained from Tobit was 67.92 indicating that the independent variables significantly explained the variation in the farmer's adoption decision. Educational level $(\beta=0.426)$ and farm experience $(\beta=0.597)$ were both positive and statistically significant at $\rho<0.05$; farm income $(\beta=0.568)$ was significant at $\rho<0.01$, and extension contact $(\beta=-0.887, \rho<0.01)$ was negative and had a negative impact on agroforestry adoption. The constraints affecting the practice of agroforestry among arable farmers were; poor policies, inadequate extension services, insufficient improved tree species among others. The study recommends intensification of extension services and provision of incentives to farmers to promote agroforestry adoption to achieve increased food production and sustainable land-use systems.
\end{abstract}

Contribution/Originality: This study is one of the very few studies which have empirically investigated agroforestry practices among arable farmers' for sustainable land-use systems.

\section{INTRODUCTION}

Arable farming involves cultivating crops on farmlands, which have usually been ploughed before planting. It involves cultivating crops such as cereals and grains, root and tubers or fruit and vegetables rather than keeping animals. Adoption is defined as an individual's or a group's decision to employ an innovation on a long-term basis [1]. The systematic application of a scientific or other organized body of knowledge to practical objectives is referred to as practice [2]. New ideas, inventions, innovations, techniques, technologies, methods, and materials are all included. Agroforestry is a type of land management where trees or shrubs are planted around or amid crops or pastureland. It incorporates shrubs and trees into agricultural and forestry methods to provide more diverse, productive, profitable, healthy, environmentally sound, and long-term land-use systems. Agroforestry comprises of two or more plant species, which may include either of the following; Khaya senegalensis, Cactaceae spp, Eucalyptus 
globulus, Azadirachta indica, Terminalia ivorensis, Vernonia amygdalina, Ocimum gratissimum, Pterocarpus mildraedii, Moringa oleifera, Carica papaya, Mangifera indica, Psidium guajava, Citrus spp, Musa spp, Irvingia gabonensis, Persea spp, Pinus spp, Chamaedorea seifrizii, vertivar grass, Psuedophoenix sargentii, etc. integrated into arable agricultural systems, resulting in numerous outputs and increased total yields [3]. One of the solutions for ensuring conservation and mitigating the effects of climate change is agroforestry. Agroforestry is a dynamic ecologically based natural resource management method that diversifies and sustains output for greater social, economic, and environmental advantages for arable farmers by integrating trees and shrubs on farms and agricultural landscapes [1] Investment in agroforestry methods can give alternative income to rural households [4]. Agroforestry activities can lower the vulnerability of rural households to income poverty. Agroforestry practices also aid in the resolution of some of the most complex and difficult environmental issues, such as rural resource management's marginal economics, disruption of soil and hydrologic cycles, air quality issues, and the extinction of rare and endangered ecosystems and species [3].

Agroforestry is an agricultural practice that involves mixing trees and shrubs with crops and/or livestock to reap the mutual benefits. It combines various plant species in a small space to create a complex ecosystem that can support a broader range of birds, insects, and other creatures Wikipedia [3]; Adekoya and Tologbonse [1] and [5]. Agroforestry is a type of farm forestry that promotes the intentional integration of woody perennials with agricultural crops and/or animals on the same management unit, with the goal of improving soil fertility and raising farmers' revenue by using economic trees [2]. Many worldwide concerns, such as deforestation, unsustainable agricultural methods, hunger, poverty, and malnutrition, are addressed by agroforestry [4]. Agroforestry encompasses a wide range of applications and practices. The categories include: Alley cropping, Boundary systems and hedge practices, home garden, woodlot practices, homestead planting practices, fodder bank innovations, Parkland practices, improved fallows, etc. The interacting benefits of agroforestry and other farming operations are a major reason for stakeholders' growing concern about the implementation of agroforestry methods [1]. Previous research on the adoption of agroforestry practices [6] concentrated on the factors that influence adoption, with neglect to the available practices in a particular region, socioeconomic benefits to rural farmers, tree and shrub species to be adopted that will suit their particular needs and the constraints of farmers adoption decisions. Low adoption of agroforestry approaches among arable farmers is also due to insufficient interaction between research, extension, and farmers [7]. Agroforestry is a key component for sustainable land-use systems. The study looked into the use of agroforestry among arable farmers in the study area, specifically the respondents' socioeconomic factors; types of agroforestry practices available to the respondents; the benefits of agroforestry practices; analyze the determinants of agroforestry practice adoption in the study area, as well as identify the barriers to agroforestry practice adoption in the study area.

\section{METHODOLOGY}

2.1. Study Area

The research was carried out in Plateau State, Nigeria, in the Bokkos Local Government Area (LGA). Bokkos LGA is located between latitude $9^{\circ} 15^{\prime} \mathrm{N}$ and longitude $8^{\circ} 53^{\prime} \mathrm{E}$ [8] and has a total size of $1682 \mathrm{~km} 2$. It has a total estimated population of 392, 0263 [8]. Annual rainfall averages 1460mm [8]. The major crops cultivated are; Irish potatoes, maize, cocoyam, sweet potato, red beans and several other vegetables. The study area is made up of eight (8) districts which are; Bokkos, Daffo, Richa, Mushere, Sha, Manguna, Kamoi and Toff [8].

\subsection{Sampling Technique and Sample Size}

The respondent farmers for the study were chosen using a multistage sampling procedure. In the first stage, two (2) districts, i.e. Bokkos and Daffor districts were purposively selected due to the prevalence of arable farmers who integrated agroforestry systems. In the second stage, three (3) villages from each of the two districts were 
chosen at random, for the Bokkos district we have; Butura, Tarangol and Ndar and for the Daffor district we have; Ngahngul, Ganda and Magyi. In the third stage, a list of 720 arable farmers in the selected districts compiled by the staff of German Society for International Cooperation, ltd. (G.I.Z), a Non-Governmental Organization (N.G.O) situated in the study area was collected. In selecting the sample size from the sample frame the Slovin formula was used; a total of 94 farmers were methodically identified and purposively selected based on their farmland's integration of tree species and arable crops, however, only 90 questionnaires were retrieved and used for the purpose of this study. The Slovin formula is specified in Equation 1;

$$
\mathrm{n}=\mathrm{N} / 1+\mathrm{Z}^{2}
$$

$\mathrm{n}=$ Sample size.

$\mathrm{N}=$ Sample frame.

$\mathrm{Z}^{2}=\mathrm{Z}$ - score / error margin (confidence level @ 95\%); confidence level @ 95\%=2.58

Hence;

$\mathrm{n}=720 / 7.656=94.04$

\subsection{Analytical Techniques}

Primary data for the study was analyzed using descriptive statistics (means and percentages), adoption index; to determine the extent to which arable farmers have adopted agroforestry practices and Tobit regression analysis; to determine the factors that influence farmer's adoption decisions.

\subsection{Adoption Index}

The adoption index was used to determine the extent of agroforestry adoption among arable farmers. The adoption index was computed for individual farmer following [9] where by adoption index (Bi) is defined implicitly in Equation 2;

$$
\mathrm{Bi}=\mathrm{E}\left(\mathrm{R}_{\mathrm{i}} / \mathrm{R}_{\mathrm{t}}\right)
$$

Where;

$\mathrm{B}_{\mathrm{i}}=$ the index of adoption by ith farmer.

$\mathrm{R}_{\mathrm{i}}=$ number of number of agroforestry practice adopted by ith farmer.

$\mathrm{R}_{\mathrm{t}}=$ total number of agroforestry practice available to the ith farmer.

$\mathrm{i}=(1 \ldots \ldots . . . \mathrm{n})$

For this study an index of $\leq 0.33,=0.5$ and $\geq 0.66$ indicates low, mid and high level of adoption index respectively. Farmers in the study area can use agroforestry practices such as;

i. $\quad \mathrm{Y}_{1}=$ Alley cropping systems.

ii. $\quad \mathrm{Y}_{2=}$ Hedge practices.

iii. $\quad \mathrm{Y}_{3=}$ Home gardens.

iv. $\quad \mathrm{Y}_{4=}$ Improved fallow practices.

v. $\quad \mathrm{Y}_{5=}$ agrosilvicultural systems.

vi. $\quad \mathrm{Y}_{6=}$ Fodder banks/woodlots.

\subsection{Model of Tobit Regression}

The association between the level of farmers' adoption index and the many factors influencing it was established using the Tobit regression model. It calculated the factors that influence the intensity or breadth of agroforestry adoption. Tobit models are statistical regression models that describe the connection between a continuous dependent variable that has been censored (or truncated) and a censored (or truncated) continuous dependent variable $\mu i$ as well as a set of independent factors $\mathrm{x}_{\mathrm{i}}$. The Tobit models, in general, assume the existence of a latent continuous variable $\mu^{*} \mathrm{i}[10]$. Tobin's approach was to change the likelihood function so that it 
represents the unequal sampling probability for each observation based on whether the latent dependent variable was above or below the threshold [11]. In its most basic version, the Tobit model [12] is stated implicitly in Equation 3:

$$
\mu * i=\beta \mathrm{x}_{i}+e
$$

For the ith farmer, the model is algebraically presented in Equation (4) and (5);

$$
\mu i=\beta_{o}+\beta_{t} \beta_{t}+\text {---------------------------- } \beta_{n} X_{n}
$$

0 if $\mu^{*} \leq \mathrm{T}$

$$
\mu i=\mu^{*} \mathrm{i} \text { if } \mathrm{o}<\mu^{*} \mathrm{i}<1(i=1 \ldots 90)
$$

1 if $\mu^{*} \mathrm{i}>\mathrm{T}$

Where:

$\mu i=$ the latent continuous variable i.e. adoption index of agroforestry practices $(1,2,3$; denoting low, moderate and high adopters);

$\beta=$ A set of unknown coefficients in a vector. $x_{i}=$ ith individual's attributes vector, and includes independent variables, which are defined as follows;

$\mathrm{X}_{\mathrm{i}}=$ vector of the explanatory variable, these include;

$\mathrm{X}_{1}=$ Educational level (years);

$\mathrm{X}_{2}=$ Household Size (number of persons);

$\mathrm{X}_{3}=$ Farming Experience (years);

$\mathrm{X}_{4}=$ Farm Size (hectares);

$\mathrm{X}_{5}=$ farm income $(\mathrm{N})$;

$\mathrm{X}_{6}=$ Extension contact (dummy variable, yes $=1$, no $=0$ ); and

$e_{i}=$ Error term

$\mu * i=$ Adoption of agroforestry practices represented as a non-observable latent variable;

$T=$ the critical (cut-off) value that corresponds to $\mu^{*}$

$i>T$ as intensity of use and $\mu^{*}$

$i<T$ as extent of use of; and

$n=$ the number of observations.

This model is more appropriate as compared to dichotomous models for the following reasons; i) It explains links between a continuous dependent variable and a group of independent variables [13]; and ii) it investigates judgments utilizing truncated or censored error terms [14]. In addition, unlike dichotomous choice models, the Tobit model analyzes the factors of the intensity and extent of farmers' adoption of agroforestry methods [14]. Tobit models don't work with discrete or binary outcomes. Linear regression is a type of Tobit model. The Tobit model is employed when a continuous dependent variable needs to be regressed but is skewed in one direction. The Tobit model allows for regression of such a variable while also censoring it, allowing for regression of a continuous dependent variable. It enables the analyst to set a lower (or larger) censoring threshold while keeping the linear assumptions required for linear regression.

Table-1. Summary Statistics of the Respondents' Socioeconomic Factors.

\begin{tabular}{l|c|c|c}
\hline Factors & Mean & Frequency & Percentage (\%) \\
\cline { 1 - 2 } Gender (male) & & 65 & 72 \\
\cline { 1 - 2 } Level of education & 11 & & \\
\cline { 1 - 2 } Household size & 9 & & \\
\cline { 1 - 2 } Farming experience (years) & 17 & & \\
\cline { 1 - 2 } Farm size (ha) & 1.2 & & \\
\cline { 1 - 2 } Farm income (N) & 147,000 & & \\
\hline Source: Field Survey (o018) & & 80 & \\
\hline
\end{tabular}

Source: Field Survey (2018). 


\section{RESULTS AND DISCUSSION}

\subsection{Respondents' Socioeconomic Characteristics}

The majority of the respondents $(72 \%)$ were male, as seen in Table 1 . This indicates a masculine gender majority. As a result, male-headed households are more likely to engage in agroforestry than female-headed households. This may be attributed to the area's socio-cultural environment, which provides males with access to productive resources, particularly farms. This corroborates with the findings of Thangata and Alavalapati [15]; Udofia [4] who also reported similar results. The respondents' average educational level was 11 years, indicating that they had completed either primary or high school. Respondents could be classified as literate as a result of this finding. Because education has a beneficial effect on the adoption of new technologies, this literate fraction of respondents means the adoption of innovations like agroforestry will be favored. Education therefore facilitates the choice and process of adoption of farm practices and innovation. This corroborates with the findings of Akinbile, et al. [2]; Molua [16] who also reported similar results. The respondents' average household size was nine individuals, indicating a good source of family labor for agriculture tasks. This supports the findings of Pattanayak, et al. [17]; Vihi, et al. [18], who found that having a large household is beneficial to farming because labor may be collected from the members. The respondents have a mean farming experience of 17years; implying that the respondents had adequate experience necessary for adopting improved farm practices and innovations. The good use of experience comes in the form of management, planning and decision making in the farm operations and activities. It is also very important in terms of coordinating farm activities. This shows that the managerial ability of farmers can be inferred to be reasonably good. The more experience a farmer has, the more efficient his decisionmaking processes are, and the more willing he is to take chances in order to increase his production. Farming experience is the process of obtaining knowledge by repeatedly practicing a skill, resulting in specialization. Farmers of arable crops benefit from experience in order to make more efficient use of restricted resources. This corroborates with the findings of Thangata and Alavalapati [15]; Vihi, et al. [18] who also reported similar results. The average farm size was 1.2 hectares, indicating that these are small-scale farmers who produce on a consistent basis. This is due to the land tenure or ownership system in the study area. The tenureship is characterized by fragmentation of farmlands. This small landholding is not conducive to the implementation of agroforestry techniques. Farm size, on the other hand, may not have a significant impact on agroforestry practices because farmers with fragmented farmland often attempt to make the most of their plots. This corroborates with the findings of Molua [16]; Pattanayak, et al. [17] who also reported similar results. The mean farm income per annum in the study area was estimated as 147,000 . The farmers posited that their farm income was grossly inadequate and therefore affected their capacity to adopt available options of agroforestry practices; income is very important in adoption process. This corroborates with the findings of Akinbile, et al. [2]; Udofia [4] who also reported similar results. Extension contact in the study area was limited and to some extent non-existent, this limits information dissemination about agroforestry practices and innovations. Most (89\%) of the respondents had no extension contact.

\begin{tabular}{l|c|c}
\multicolumn{3}{l}{ Table-2. Respondent distribution based on the types of agroforestry practices adopted. } \\
\hline Agroforestry & Frequency* & Percentage (\%) \\
\hline Home garden & 86 & 95.6 \\
\hline Fodder banks/woodlots & 74 & 82.2 \\
\hline Agrosilvicultural systems & 63 & 70 \\
\hline Improved fallow practices & 35 & 38.9 \\
\hline Hedge practices & 28 & 31.1 \\
\hline Alley cropping system & 17 & 18.9 \\
\hline Note: * Multiple responses.
\end{tabular}

Frequency of extension contact affects farmer's adoption decisions particularly with regards to technical and institutional support. Farmers are motivated and exposed to innovations through regular contact with extension 
agents, who also provide knowledge on how to use the technologies. Extension agents' persuasion and conviction are likely to boost acceptance of agroforestry technologies. This is consistent with the findings of Thangata and Alavalapati [15], who found comparable outcomes.

\subsection{Types of Agroforestry Practices Adopted}

Table 2 shows the distribution of respondents according to the types of agroforestry practices they used. Most (95.6\%) of respondents practiced home garden, fodder banks/woodlots (82.2\%), agrosilvocultural systems (70\%), improved fallow practice $(38.9 \%)$, hedge practice $(31.1 \%)$, alley stems (18.9\%). However, the adoption of available agroforestry practices in the study area was significantly hampered by factors such as; land tenure rights, low awareness of agroforestry practices, cost of adoption, farm income, etc. This corroborates with the findings of Torquebiau [19]; Mercer [20]; Udofia [4] who also reported similar results.

Table-3. Distribution based on the benefits derived from adopting agroforestry practice.

\begin{tabular}{l|c|c}
\hline Benefits & Frequency* & Percentage (\%) \\
\hline Alternative income source & 45 & 50 \\
\hline Soil improvement/conservation & 79 & 88 \\
\hline Food/Fruits & 87 & 97 \\
\hline Boundary marks/Wind breaks & 22 & 24 \\
\hline Wood fuel/Firewood & 58 & 64 \\
\hline Climate variability mitigation & 30 & 33 \\
\hline fodder for animals & 50 & 56 \\
\hline Biodiversity conservation & 25 & 28 \\
\hline Aesthetic/shade & 15 & 17 \\
\hline Medicinal purpose & 28 & 31 \\
\hline
\end{tabular}

Note: $*$ Multiple responses.

\subsection{Benefits of Adopting Agroforestry Practices}

The result in Table 3 show the benefits the respondents derive from adopting the various agro forestry practices in the study area. The significant benefits of adopting agroforestry practices include: food/fruits (97\%), because when suitable tree species are selected, they do not compete for resources with crops. They can instead diversify farm yields to include non-timber forest products such as fruits, nuts, mushrooms, and so on. These can result in more closed nutrient cycling, particularly in home gardens and agrosilvicultural systems. Soil improvement/conservation (88\%) is achieved through agroforestry practices, which keep soil organic matter and biological activity at levels suitable for soil fertility. Through organic matter retention and the effects of tree roots, they can maintain more favorable soil physical properties than monocropping systems. Wood fuel/firewood (64 \%), farmers save time and money by having firewood available directly from their own land. They don't have to buy fuel wood or spend time gathering wood from forests. Fodder for animals (56\%), sustainable agroforestry systems can serve as complementary livestock fodder. Agroforestry systems diversify farm production, resulting in income streams from diverse farm produce (50\%) as an alternative income source. Climate variability mitigation (33\%), trees are especially beneficial to farmers who do not have access to irrigation, they improve soil structure and increase organic matter content in soils, and they also promote soil water retention capacity. Their crowns protect larger areas of land from direct sunlight and help to reduce evaporation. Soils stay moist for longer periods of time, allowing crops to get more water from the upper soil layers where their roots are. In recent years, there has been a lot of focus on the role of agroforestry in climate change mitigation and adaptation. Agroforestry is one of the primary climate mitigation practices used in agriculture, according to the United Nations Framework Convention on Climate Change (UNFCCC). According to the Climate Institute, agroforestry lands contain the same or even more organic soil carbon than some natural woodlots. Trees are extremely efficient at absorbing atmospheric carbon and using it to form their bodies, but they also improve soil quality by making soils rich in organic matter and capable of storing more carbon than other cultivated soils. Farmers benefit from a wide range of medical goods, 
such as moringa, scented leaves, and other medicinal plants, in sustainable agroforestry systems (31\%). Agroforestry methods support biodiversity by providing a favorable environment for insects, animals, and plants, which helps to conserve biodiversity (28\%). Other benefits include; boundary marks/wind breaks (24\%) and aesthetic/shade (17\%). This result is an indication of that adopting agroforestry practices on arable farmlands has several significant benefits, especially for long-term land-use systems. This corroborates with the findings of Neupane and Thapa [21]; Sood and Mitchell [22]; Pearce and Mourato [23]; Franzel, et al. [24] who also reported similar results.

Table-4. Respondent distribution based on the index of adoption of agroforestry practices.

\begin{tabular}{l|c|c}
\hline Adoption index & Frequency & Percentage \\
\hline Low $(\leq 0.33)$ & 63 & 70 \\
\hline Medium $(=0.5)$ & 19 & 21.1 \\
\hline High $(\geq 0.66)$ & 8 & 0.09 \\
\hline Mean index $=0.27$ & & \\
\hline Source: Field Survey (2018).
\end{tabular}

\subsection{Agroforestry Practice Adoption Index}

The results in Table 4 revealed that the majority (70\%) of the arable farmers had a low level index of adoption, implying that agroforestry practices were not widely adopted among arable farmers in the study area. The estimated mean index of agroforestry practice adoption among arable farmers in the study area was 0.27 ( $\leq 0.33)$. This level of adoption index can be attributable to factors such as; farmer's socioeconomic variables, low awareness on the benefits of adoption, cost of adoption, inadequate expertise required for adoption of agroforestry practices, lack of incentives for adoption, etc. This corroborates with the findings of Molua [16]; Rice [25] who also reported similar results.

Table-5. Determinants of Adoption of Agro Forestry Practices.

\begin{tabular}{|c|c|c|c|}
\hline Variables & Coefficient & Standard error & t-value \\
\hline Constant & $0.615^{* * *}$ & 0.239 & 2.573 \\
\hline Education & 0.426 *** & 0.158 & 2.696 \\
\hline Household size & $0.486^{\mathrm{n} . \mathrm{s}}$ & 0.326 & 1.491 \\
\hline Farming experience & $0.597^{*} *$ & 0.214 & 2.781 \\
\hline Farm size & $-0.350^{\mathrm{n} . \mathrm{s}}$ & 0.261 & -1.341 \\
\hline Farm Income & $0.568 * * *$ & 0.147 & 3.863 \\
\hline Extension contact & -0.887 *** & 0.193 & -4.596 \\
\hline $\begin{array}{l}\text { Prob }>\text { chi }^{2}=0.002 \\
\text { Log likelihood }=67.92\end{array}$ & & & \\
\hline
\end{tabular}

\subsection{Factors Influencing Agroforestry Practice Adoption}

The result in Table 5 revealed the log-likelihood obtained from Tobit was 67.92 indicating that the independent variables significantly explained the variation in arable farmer's adoption decisions. This means that the independent variables of education $\left(\mathrm{X}_{1}\right)$, farm experience $\left(\mathrm{X}_{3}\right)$, farm income $\left(\mathrm{X}_{5}\right)$, and extension contact $\left(\mathrm{X}_{6}\right)$ all had a significant impact on and explained 68 percent of the variation in the adoption index of arable farmers in the study area. Furthermore, household size $\left(\mathrm{X}_{2}\right)$ and farm size $\left(\mathrm{X}_{4}\right)$ had no significant effects on arable farmers' adoption index. As a result, the interpretation of the regression result suggests the following;

Farmers' Educational Level: The coefficient of farmers' educational level (0.426) was positive and statistically significant at the $5 \%(\mathrm{p}<0.05)$ level, implying that the more educated the farmers were, the more probable they were to adopt agroforestry practices. This is consistent with the findings of Molua [16], who reported similar results on farmer participation in agroforestry practices.

Farmers' Experience: The coefficient of farmers' experience (0.597), at the $5 \%(\mathrm{p}<0.05)$ level, was positive and statistically significant, implying that more experienced farming households adopted agroforestry practices more 
than less experienced farming households. This is consistent with the findings of Akinbile, et al. [2] who reported similar findings on farmer participation in agroforestry practices.

Farm Income: The farm income coefficient (0.568) was positive and statistically significant at the $1 \%(\mathrm{p}<0.01)$ level, implying that increased farm income increases farmers' capacity to adopt agroforestry practices. This is consistent with the findings of Pattanayak, et al. [17] who found similar results in terms of farmer participation in agroforestry practices.

Access to Extension Contact: Farmers' access to extension contact (-0.887) was negative but statistically significant at the $1 \%(\mathrm{p}<0.01)$ level, this indicates an inverse relationship with farmer's adoption decisions, implying that as farmer's access to extension contact declines the adoption of practices and innovations also declines. Farm households with improved access to extension contacts will tend to adopt more options of agroforestry practices. This is consistent with the findings of Molua [16], who reported similar findings regarding farmer participation in agroforestry practices.

Table-6. Distribution of respondents based on the barriers to agroforestry adoption.

\begin{tabular}{|c|c|c|}
\hline Constraint & Frequency* & Percentage \\
\hline Land and tree tenure policies & 86 & 96 \\
\hline Low awareness of agroforestry practices & 54 & 60 \\
\hline Inadequate expertise required for adoption & 65 & 72 \\
\hline Benefits require a long gestation time & 41 & 46 \\
\hline High cost of adoption & 75 & 83 \\
\hline Demand for arable land has increased & 23 & 26 \\
\hline Taboos and traditional beliefs & 13 & 14 \\
\hline Complexity & 31 & 34 \\
\hline
\end{tabular}

\subsection{Constraints to Agroforestry Adoption}

According to the respondents in Table 6, the following were the major barriers to adopting agroforestry practices; problem of land and tree tenure policies (96\%), high cost of adoption of agroforestry practices (83\%), inadequate expertise required for adoption of agroforestry practices (72\%) and low awareness of agroforestry practices (60\%). Land tenure constraints may pose a barrier for agroforestry, particularly in countries where farmers produce communal land under conventional tenure arrangements that deny them ownership or exclusive use rights to the trees on their fields [14]. Land tenure and tree rights may be independent from land tenure, according to National Bureau of Statistics (NBS) data on agroforestry in 2007, and both land and tree tenure uncertainty may prevent people from adopting agroforestry. Farmers may be discouraged from planting new trees because they may not be the ones to harvest them after they have been established on the land [14]. The inability to recognize the advantages of trees planted over lengthy periods of time may deter farmers from planting trees. When considering the sluggish development rate of most tree products and the significantly longer time span during which benefits are realized, the relative advantage of agroforestry approaches is significantly diminished [6, 7]. Farmers are more concerned with short-term rewards and are uninterested in non-quantifiable benefits such as erosion prevention and soil protection. Another major barrier to farmers embracing agroforestry was a lack of knowledge and ability in agroforestry operations [14]. Agroforestry producers' usage of the method may be hampered by a lack of knowledge and abilities in various agroforestry practices. Most farmers lack the knowledge necessary to establish tree and shrub nurseries, pre-treat seeds, and undertake tree pruning. According to Adekoya and Tologbonse [1] when rural farmers lack access to expertise and information that would help them achieve optimum agricultural productivity, they are driven to metropolitan centers in quest of formal work as their only alternative for survival. One of the greatest impediments to the implementation of better forest management methods could be a lack of understanding. Farmers may be unaware of or misinformed about these practices. Many stakeholders are still unaware of the potential for agroforestry methods to bring medium and long-term advantages to both individuals and the general public [14]. This suggests that farmers' incapacity to appraise the profitability 
of agroforestry practices in comparison to other options could be due to a lack of awareness and interest. In order to enhance their awareness and interest in agroforestry techniques, farmers need more information and training on agroforestry in comparison to other agricultural operations, which limits the adoption of particular practices [14]. Furthermore, the cost of implementing agroforestry practices is typically high in terms of seedlings, tree kinds, and labor needs for establishment, which is a major issue that influences farmer adoption decisions. This discovery is consistent with the findings of Pearce and Mourato [23], who found comparable outcomes.

\section{CONCLUSION}

Agroforestry techniques among arable farmers in Bokkos LGA, Plateau state, Nigeria, were investigated in this study. According to the findings, agroforestry methods were adopted at a low rate, which can be attributed to socioeconomic issues that influenced farmer adoption decisions. A variety of options of agroforestry practices were available but not adopted by the farmers. Also, the results revealed that agroforestry systems have several benefits including; food/fruits, boundary marks/windbreak, wood fuel/firewood, soil improvement/conservation, aesthetic/shade, fodder for animals, herbal medicine, alternative income, mitigation of climate variability and biodiversity conservation. The regression analysis revealed that education, farming experience, farm income, and extension contact were the most important factors impacting agroforestry practice adoption. According to the respondents, the problem of land and tree tenure rights, long gestation periods of tree species, inadequate sensitization and expertise on agroforestry practices, and the cost of adopting agroforestry inputs and practices were the major barriers to adoption of agroforestry practices. Improved policy formulation and implementation, increased extension services, development of improved tree species and subsidizing the cost of agroforestry inputs are strongly recommended to mitigate the adoption constraints of agroforestry practices for sustainable land-use systems. In addition, government as well as other stakeholders can subsidize and intensify the supply of agroforestry inputs to farmers. Extension operations should also be stepped up to raise awareness and provide incentives for farmers to embrace agroforestry practices. Furthermore, empirical studies on specific tree varieties and shrub species to be adopted to suit the needs of the farmers should be undertaken.

Funding: This study received no specific financial support.

Competing Interests: The authors declare that they have no competing interests.

Acknowledgement: The study was developed by the first author, who also conducted the statistical analysis and prepared the protocol and initial draft of the publication. The study's analyses were overseen by the second and third authors. The literature searches were handled by all of the authors. In addition, the final manuscript was read and approved by all writers.

\section{REFERENCES}

[1] A. E. Adekoya and E. B. Tologbonse, Adoption and diffusion of innovations", In Adedoyin, S.F (2005) (ed) Agricultural Extension in Nigeria vol. 251: ARMTI Ilorin, AESON, 2005.

[2] L. Akinbile, K. Salimonu, and O. Yekinni, "Farmers' participation in agroforestry practices in Ondo State, Nigeria," Research Journal of Applied Sciences, vol. 2, pp. 229-232, 2007.

[3] Wikipedia, "Agroforestry: Retrieved from: https://en.wikipedia.org/wiki/Agroforestry [Accessed 7th October, 2018 ]," 2018.

[4] S. I. Udofia, "The role of agroforestry practices in checking environmental Degradation" In forestry and sustainable development," in Proceeding of the First Workshop Association of Nigeria, AkwaIbom State Branch Udo, E.S. (ed); 10th-11th April, 2001. FAN/UNDP/AKSMOE/Department of Forestry and Wildlife, University of Uyo, 2001, pp. 45-52.

[5] FAO, Global forest resources assessment 2010. Rome: FAO, 2010.

[6] O. Ajayi, "Acceptability of sustainable soil fertility management technologies: Lessons from farmers' knowledge, attitude and practices in southern Africa," Journal of Sustainable Agriculture, vol. 13, pp. 18-2 1, 2006. 
[7] C. L. Aboh and I. A. Akpabio, "Gender and analysis of common agroforestry practices in AkwaIbom State, Nigeria," Agricultural Journal, vol. 3, pp. 185- 89, 2008.

[8] NBS, The Nigerian statistical fact sheets on economic and social development. Abuja: National Bureau of Statistics, 2007.

[9] D. Phillip, M. Maiangwa, and B. Phillip, "Adoption of maize and related technologies in the north west zone of Nigeria," Moor Journal of Agricultural Research, vol. 1, pp. 98-105, 2000.

[10] W. Greene, "Marginal effects in the censored regression model," Economics Letters, vol. 64, pp. 43-49, 1999.Available at: https://doi.org/10.1016/s0165-1765(99)00059-2.

[11] P. Kennedy, A guide to econometrics, 5th ed. Cambridge: MIT Press, 2003.

[12] D. N. Gujarati, Basic econometrics, 4th ed. New Delhi: Tata McGraw-Hill Publishing Company Limited, 2004.

[13] W. Greene, Econometric analysis, 5th ed. New Jersey: Prentice Hall, 2003.

[14] S. Vihi, O. Adedire, and B. Ngu-Uma, "Adoption of agroforestry practices among farmers in gwaram local government area of Jigawa State, Nigeria," Asian Journal of Research in Agriculture and Forestry, vol. 4, pp. 1-13, https://doi.org/10.9734/ajraf/2019/v4i430069 2019.

[15] P. Thangata and J. R. Alavalapati, "Agroforestry adoption in southern Malawi: The case of mixed intercropping of Gliricidia sepium and maize," Agricultural Systems, vol. 78, pp. 57-71, 2003.Available at: https://doi.org/10.1016/s0308-521x(03)00032-5.

[16] E. L. Molua, "The economics of tropical agroforestry systems: The case of agroforestry farms in Cameroon," Forest Policy and Economics, vol. 7, pp. 199-2 11, 2005.Available at: https://doi.org/10.1016/s1389-9341(03)00032-7.

[17] S. K. Pattanayak, D. E. Mercer, E. Sills, and J.-C. Yang, "Taking stock of agroforestry adoption studies," Agroforestry Systems, vol. 57, pp. 173-186, 2003.

[18] S. Vihi, B. Jesse, A. Dalla, and Y. Sadiku, "Assessment of forestry laws compliance among farmers in rural forest communities of Plateau State, Nigeria," Asian Journal of Research in Agriculture and Forestry, vol. 5, pp. 33-46, 2020.Available at: https://doi.org/10.9734/ajraf/2020/v5i430093.

[19] E. F. Torquebiau, "A renewed perspective on agroforestry concepts and classification," Reports from the Academy of Sciences-Series III-Life Sciences, vol. 323, pp. 1009-1017, 2000.Available at: https://doi.org/10.1016/s07644469(00)01239-7.

[20] D. E. Mercer, "Adoption of agroforestry innovations in the tropics: A review," Agroforestry Systems, vol. 61, pp. 31 1-328, 2004.Available at: https://doi.org/10.1023/b:agfo.0000029007.85754.70.

[21] R. P. Neupane and G. B. Thapa, "Impact of agroforestry intervention on soil fertility and farm income under the subsistence farming system of the middle hills, Nepal," Agriculture, Ecosystems \& Environment, vol. 84, pp. 157-167, 2001.Available at: https://doi.org/10.1016/s0167-8809(00)00203-6.

[22] K. K. Sood and C. P. Mitchell, "Household level domestic fuel consumption and forest resource in relation to agroforestry adoption: Evidence against need-based approach," biomass and Bioenergy, vol. 35, pp. 337-345, 2011.Available at: https://doi.org/10.1016/j.biombioe.2010.08.045.

[23] D. Pearce and S. Mourato, The economic valuation of agroforestry's environmental services. In: Agroforestry ad Biodiversity Conservation in Tropical Landscapes, Schroth, G., da Fonseca, G.A.B., Harvey, C.A., Gascon, C., Vasconcelos, H.L., Izac, A.M.N. Washington, USA: Island Press, 2004.

[24] S. Franzel, D. Phiri, and F. Kwesiga, Assessing the adoption potential of improved fallows in Eastern Zambi" In: Franzel S. and Scherr, S. J. (eds.) Trees on the Farm: Assessing the adoption potential of agroforestry adoption in Africa. CAB International: Wallingford, U.K, 2002.

[25] R. A. Rice, "Agricultural intensification within agroforestry: The case of coffee and wood products," Agriculture, Ecosystems \& Environment, vol. 128, pp. 212-218, 2008.Available at: https://doi.org/10.1016/j.agee.2008.06.007.

Views and opinions expressed in this article are the views and opinions of the author(s), Journal of Forests shall not be responsible or answerable for any loss, damage or liability etc. caused in relation to/arising out of the use of the content. 